\title{
HAWANA
}

Aristotle's Poetics, Bharatamuni's Natyasastra, and Zeami's Treatises: Theory as Discourse Author(s): Graham Ley

Source: Asian Theatre Journal, Vol. 17, No. 2 (Autumn, 2000), pp. 191-214

Published by: University of Hawai'i Press

Stable URL: http://www.jstor.org/stable/1124489

Accessed: 26/01/2009 04:32

Your use of the JSTOR archive indicates your acceptance of JSTOR's Terms and Conditions of Use, available at http://www.jstor.org/page/info/about/policies/terms.jsp. JSTOR's Terms and Conditions of Use provides, in part, that unless you have obtained prior permission, you may not download an entire issue of a journal or multiple copies of articles, and you may use content in the JSTOR archive only for your personal, non-commercial use.

Please contact the publisher regarding any further use of this work. Publisher contact information may be obtained at http://www.jstor.org/action/showPublisher?publisherCode=uhp.

Each copy of any part of a JSTOR transmission must contain the same copyright notice that appears on the screen or printed page of such transmission.

JSTOR is a not-for-profit organization founded in 1995 to build trusted digital archives for scholarship. We work with the scholarly community to preserve their work and the materials they rely upon, and to build a common research platform that promotes the discovery and use of these resources. For more information about JSTOR, please contact support@jstor.org.

University of Hawai'i Press is collaborating with JSTOR to digitize, preserve and extend access to Asian Theatre Journal. 


\title{
Aristotle's Poetics, Bharatamuni's Natyasastra, and Zeami's Treatises: Theory as Discourse
}

\author{
Graham Ley
}

\begin{abstract}
Scholars have often pursued comparative studies of major traditions of theatrical theory (Greek, Sanskrit, and nō), and the theories themselves are often used as windows on vanished modes of performance. This article, however, considers the theoretical treatises as discourses that advance claims about the status of theatre and establish value through the creation of standards for achievement. The author situates treatises on the art of theatre in the context of philosophical debate (Greek), religious and ethical writing (Sanskrit), and courtly aesthetics (Japanese) and examines the question of discursive communities and those to whom theatrical theory is addressed.

Graham Ley studied Greek at the University of Oxford and Renaissance culture at the Warburg Institute in London. He lectures in drama at the University of Exeter, where he teaches a comparative course on theatrical and performance theory. His study of European and American theory, From Mimesis to Interculturalism: Readings of Theatrical Theory Before and After Modernism, was published in 1999, and he has written widely on performance in the ancient Greek theatre.
\end{abstract}

Comparisons between the Greek and nō theatres, and between the Greek and Sanskrit theatres and the theoretical writings associated with them, have their own traditions in modern scholarship and take a variety of forms. ${ }^{1}$ Inevitably insights about the qualities of the original theatrical experience are a major objective of such comparisons. The theoretical writings can be seen credibly as repositories of information capable, to a degree, of being recomposed into understanding and appreciation. In addition, certain leading concepts, such as those that gather round the English word "imitation" (Greek mimesis, Sanskrit anukarana, Japanese monomane) predictably attract major critical attention. 
Treating all three bodies of writing as forms of composition or discourses in their own right is an alternative approach that can yield different results and illuminate different aspects of theory and its relationship to practice. The material is complex, of course, and any initial treatment is bound to have its limitations. Here I want to consider various characteristics of the Poetics, the Natyasastra, and Zeami's treatises under two provisional headings. The first, context and status, is documentary in tone. The second, the discourse of theory, includes critical analysis of writings.

\section{Context and Status}

The Poetics of Aristotle has a wide and discernible context that embraces texts now known only by name or inference. It begins in the work itself, which almost certainly included a second part on comedy and may well have contained an excursus on katharsis that amplified the minimal mention of the concept in what survives of the text. ${ }^{2}$ In addition, Aristotle is known to have written a work, On Poets, in dialogue form and in three books, as well as books on Victories in the Festivals of Dionysos and on Records of Production (Didaskaliai). The last of these were certainly documentary rather than critical or theoretical. These works should be placed alongside six books of Homeric Problems - which may have been related to the kind of treatment epic receives in the later part of the surviving text of the Poetics-and a work On Music.

The surviving Poetics is an esoteric work, which means that it was closely associated with Aristotle's oral teaching in his school, the Lykaion (Lyceum). This status contrasts with the lost On Poets, which belonged to the exoteric works designed to be reproduced in manuscript and read outside the school. One should note that the written dialogue form had been thoroughly established by Plato as a mode of promulgating the advantages of the pursuit of spoken, philosophical dialectic. There is, of course, a remarkable irony here: Aristotle's $O n$ Poets has disappeared into minimal fragments, while his Poetics has had a massive influence as writing in the public domain. But further questions remain: what exactly was retained for oral teaching, and why was it retained? Aristotle's intentions cannot be known, nor is it clear how the esoteric writings (all of the works we have by Aristotle) came to replace the exoteric writings in circulation. One possible answer is that this kind of retention within the teaching system might relate to a sense of an exclusive audience (plausibly his pupils) and transmission within the school (of ideas to successive teachers). ${ }^{3}$

Certain aspects of context and status are perhaps less problematic. Aristotle in his documentary works on the dramatic festivals is clearly concerned with the record-and hence with the formation of 
what we might call a classic sense of achievement in drama. This is plainly a characteristic of the Poetics, which is not by any means a manifesto for initiative or change. This consolidation of a classic sense is also apparent in the contemporary activities associated with Lykourgos in Athens, where Aristotle was repeatedly resident. The theatre of Dionysos received a lavish reinstatement in stone, which must have fixed the form in which dramas might be played; Lykourgos also assured a definitive collection of past playscripts and secured finance for statues of playwrights. We can also be reasonably clear about the existence of a kind of writing called a techne, or an "art." What these treatises exactly contained is unknown, but they were written on a specific skill often by a practitioner. Sophocles wrote a treatise On the Chorus; the sculptor and bronze-caster Polykleitos wrote a Canon (his famous statue Spear-Carrier or Doryphoros was also called “The Canon"); and other specialist works are also testified. The absence of a techne on dramaturgy permits Aristotle to write one.

Quite why he should is another matter, and in this respect the evidence of his Rhetoric is interesting. The Rhetoric is itself a techne, of what could be considered an unrespectable art, and Aristotle is clearly aiming to provide rhetoric with a respectable and indeed a philosophically sound status as a public activity. Public speaking, in the political or legal spheres, was a major constituent of Athenian public life, but Aristotle was of the opinion that many of its more serious aspects had not been considered in any previous written treatment (techne) of the art. In book 3 of the Rhetoric, in writing of the importance of "delivery" or "performance" by the orator or the actor, Aristotle incidentally notes that "in the case of tragedy actors now have more effect than the poets," and it is clear that he is thinking of success in the dramatic competitions (Aristotle 1991, 216). ${ }^{4} \mathrm{~A}$ theory of the emotions related to that in the Poetics; a consideration of "style" or lexis, also prominent in the Poetics; the importance of argument, rhythm, and the arrangement of the parts of a speech-all suggest that the rehabilitation of rhetoric as a serious and social art in the Rhetoric offers us a helpful context for understanding the discursive context of the Poetics.

The final and overwhelming part of the context is the formulation of the status of philosophy, and I shall return to this issue in the following section. Inherited concepts are of great importance, and much of our understanding of the Poetics and its influence depends on appreciating the significance of the Platonic term "mimesis." Platonic philosophy, like that of Aristotle, is deeply political, concerned with the values and practices of the polis and its inhabitants, and the principal claim of Platonic philosophy was to a close relationship with truth. These two characteristics combine to make philosophical discourse 
supposedly the most powerful and secure discourse, capable of subjecting social practice to a controlling analysis. The Poetics is supported by a web of such philosophical analyses and arguments having to do with cognition, ethics, and psychology. Drama is something to be known, not merely practiced, and to be knowable it needs to be identified or fixed in best practice. ${ }^{5}$

The Natyasastra is undoubtedly a compendium, and as such it is open to interesting or frustrating questions about authorship and to what one might call the analytic or unitarian tendencies-namely, the inclination to believe that the compilation is (respectively) the work of many or substantially of one. ${ }^{6}$ As a consequence, its date is open to debate, as well, and arguments exist for placing it between about the fourth century B.C. and a millennium later. The situation is not helped by uncertainty about the dates or eras of other significant Sanskrit writings. The mythical figure of Bharata as a sage with disciples, one who is capable of cursing an aberrant performer, is prominent in one of the plays of Kalidasa, Vikramorvasiya, and the ironic mythology of the playwright accords perfectly well-in a minimal way-with what is found in the Natyasastra. But even a fixed or nearly certain date for the activity of Kalidasa would not in principle inform us greatly about the relationship between theory and practice. ${ }^{7}$

But there are more substantial indicators of a context that is bound up closely with status. The claim of the treatise as it stands is that of a fifth Veda, a position that might otherwise be accorded to itihasa, or mythical learning, as represented by epic poetry, notably the Mahabharata; ${ }^{8}$ I shall return to this issue later. But the status of the theatre itself is far more dubious. The performers of drama are cursed with a position in the lowest caste of Sudras, while the theory and the mythical status of its compiler Bharata are clearly raised above that demeaning level. This dilemma advertises a problematic role for the compendium in its first principles-and in particular for the status of the natyacarya and the sutradhara who control and direct the activities of a company of players.

There are further aspects of context that present themselves immediately. The compilation of a sastra on the theatre plainly invites comparison with the status of other sastra writings, such as the Manu Smrti on dharma (duty, religious and social obligation), the Arthasastra (ascribed to Kautilya) on artha, worldly good, and hence politics, and the Kamasutra (of Vatsyayana) on kama, or pleasure, specifically sexual satisfaction. The generally discursive sastra literature of treatises follows the esoteric sutra literature of condensed aphorisms, originally associated with cult and the rituals observed in the Veda literature. ${ }^{9}$ The Natyasastra itself insists (in chapter 35) that knowledge of the 
other sastra writings is essential for the sutradhara (usually translated as the "director" of the company); the three varieties of the stage building are originally conceived, it is claimed, in accordance with the sastra literature. As a text, the Natyasastra is plainly writing itself into a complex intertextuality.

Religious sanction is thoroughly apparent, not only in the founding or charter myth of the opening section (and in chapters 22 and 36 ), but in the subsequent and precise instructions for preparing a playhouse and for the preliminaries of performance. Bharata is a sage who is invited by the gods to assume the implementation of the fifth Veda invented by Brahma, compiled from elements of the other four, but unlike them open to those of the Sudra caste. Despite this last provision, theatrical performance initially pertains to the gods as audience, and even to the demons, and the gods are installed all over the stage. A further performance concerned with dharma, kama, and artha is then shown to Siva, who provides the religious sanction for dance in drama. But the extent to which the activity is placed in the ritual world by this fifth Veda is apparent in the roles prescribed for the natyacarya in the worship of the stage, where he takes over from the opening prayers of the Brahmins (chapter 3), and for the sutradhara in the preliminaries to performance, in which he is succeeded by the sthapaka (introducer), who should resemble the sutradhara and is himself a Brahmin. The distinction between natyacarya and sutradhara in the Natyasastra is by no means clear, but the treatise affords them the role of priests in ritual observation consonant with the Vedas, and comprehensive in its scope. ${ }^{10}$ From conception to the moment of performance the Natyasastra ensures an unbroken thread of religious engagement for the theatre.

The ritual is not, however, the only form of status assured to the theatre by the sastra. Appropriate conduct, as described and prescribed in the sastra literature, will not only be religious in its orientation. The categorization with which the Natyasastra abounds is part of a scheme of order, of appropriateness, which may be applied as much to character as to gesture. The discipline of the allocation of Sanskrit and Prakrit speech to characters (in chapter 18) acknowledges the distinctions of caste and the demeaning circumstances that may qualify caste status, while the modes of address to be followed in drama (chapter 19) secure conformity with the established order. In this respect the compilation of rules in the sastra is an assurance to authority of respectability for the practice of theatre. Hence what may appear as no more than an established formulaic opening to chapter 19, addressed to the best of the Brahmins who have questioned Bharata from the beginning of the treatise, actually presents order to those at its apex. The creation 
of a sastra, not the creation of drama, is the continuing subject of the Natyasastra, and that creation offers both context and status to a theatre practice, which is all the more likely to wish to conform to its precepts for just those reasons.

In the Natyasastra, it is the "sons of Bharata" who are to carry on and perform the tradition established by their father and received from Brahma and Siva. In the coda to Shügyoku tokka, Takeda Komparu Hachemon records in 1656 that as a result of the unlucky death of his elder brother, Ujikatsu Shichirō, his father had felt it necessary to pass on the "secret book" to him (Rimer and Yamazaki 1984, 147).11 He himself is now passing it on to his successor, since "the line of transmission must not be allowed to be interrupted." This short statement reflects, somewhat pathetically, what had happened at the death of Zeami's older son, Motomasa, in 1432, an event that confirmed the transmission of Zeami's written teachings out of the male succession to his sonin-law Komparu Zenchiku. ${ }^{12}$ For Takeda Komparu Hachemon the possession of texts is a signal of the right to succeed: "Since the beginning, these secrets were given to the head of the house alone and it has never been permitted for other children or other descendants to make inquiries concerning these profound secrets" (Rimer and Yamazaki 1984, 147). For Zeami, writing the original treatise on the no (Füshikaden; 1402 with later additions) had been an initiative undertaken explicitly to record the teachings of his father Kan'ami, who had died in 1384. The testament was to serve the "house" of his family, and perhaps the most explicit occasion for its composition was Zeami's sense of a decline in the $n \bar{o}$. This is first expressed as a fear in Füshikaden (from 1400) but quickly turns into a statement in the same work (from 1402) and reappears later in Shikadō of 1420 as a constant if theoretical conviction (pp. 30, 37, and 72 respectively). The motif of decline is not hard to trace in Aristotle's attitude to the art of tragedy, and the threat of decadence is a minor mythical theme in the Natyasastra as well. Like success, it is a prominent motive for the creation of theoretical texts, and it is inevitably used to affirm a normative code.

The motif of decline, in alliance with the transmission of a secretive authority, not only issues the strongest imperative to the succession but also presupposes a history of achievement. In his coda to Shügyoku tokka, Takeda Komparu Hachemon takes the line of transmission back to "our ancestor Hata no Kōkatsu." In doing so he reiterates and affirms the genealogy of $n \bar{o}$ constructed for his successors, and in honor of his father, by Zeami at the start of his first treatise, Füshikaden. In this genealogy, Hata no Kōkatsu was commissioned by Prince Shōtoku to provide entertainments called sarugaku for the sake of peace, and this art was inherited by his descendants, to be performed at the 
shrines of Kasuga and Hie. A religious sanction for the ancestral $n \bar{o}$, performed for the public good, is allied to imperial patronage, in a prefiguring of the patronage extended by the shogun to Kan'ami and his son Zeami. The mythology is elaborated later in Füshikaden, when the actions of Shōtuku are doubled by those of the Emperor Murakami, who revives the patronage by extending it to a successor of Kōkatsu named Hata no Ujiyasu. His descendant is identified as the head of the Komparu company by Zeami (pp. 34-36).

Sarugaku is dignified in its history by these associations. There exists a description of a sarugaku entertainment from the eleventh century by Fujiwara no Akihira, which includes mimetic pieces alongside juggling and acrobatics, featuring such figures as an aged local magistrate, a frightened monk, "a respected nun who... seeks the gift of swaddling clothes for the baby shortly to be born," and "the official ... believed to be a serious man [who] one day whistles unintentionally the tune of a flute" (Inoura 1971, 43-44). Chinese san-yueh, "which included comic mime, singing and dancing, as well as acrobatics and conjuring tricks," was "transmitted to Japan in the eighth century, both from China itself and from Korea" (Konishi 1991, 520). The performers of sarugaku were originally "exempted from taxes and labor levies," and when this exemption was withdrawn in $\mathbf{7 8 2}$ many chose to remain outside the census and hence were considered and effectively classed as outcasts: semmin (ibid.). The continuing fragility of social status for the performer even in the later period is reflected in the disappoval of the aristocrat Go-oshikoji Kintada for the favor shown by the shogun to the boy Zeami: "Sarugaku like this is the occupation of beggars, and such favor for a sarugaku player indicates disorder in the nation" (Hare $1986,16)$. Indeed, as modern biographical studies have disclosed, patronage was to desert Zeami later.

But Sarugaku nō is given more than a recurrent myth of high patronage to enhance its functional discipline of self-respect. Although he seemingly dismisses an origin in India and a time scale that stretches back to the gods at the opening of Füshikaden, Zeami returns to both themes with greater conviction and to greater effect later in the treatise. The story of the dance of Uzume drawing the sun goddess Amaterasu from the cave, which may be found in the cosmogony of the eighth-century Nihongi, becomes a foundation myth for sarugaku (Rimer and Yamazaki 1984, 31-32). ${ }^{13}$ This initiative by Zeami parallels the divine myths for the origin of poetry proposed in the famous preface by Tsurayuki to the first imperial anthology, Kokin Waka Shu , of the ninth century. India assumes significance because it permits Zeami to ascribe a Buddhist origin to sarugaku and claims precedence over China, the true historical source of san-yueh, which is nonetheless per- 
mitted to enter the multiple frame as the spiritual nationality of Hata no Kōkatsu (pp. 32-33).

The relationship of the creation and composition of the treatises to the poetics of waka and linked verse is most apparent in the adoption of the value term "yugen" (often translated as "grace"), but the centrality of the flower imagery cannot be ignored. ${ }^{14}$ It is found in Tsurayuki and Yoshimoto, a contemporary of Zeami's father, whose influence on Zeami has been alleged, and Zeami's appropriation of yugen and the flower to the actor's performance represents his most profound theoretical elevation of the disciplined art of the $n \bar{o} .{ }^{15}$ In Füshikaden, Zeami admitted that yugen was traditionally identified with a rival style of sarugaku, the Omi, in contrast to the traditional identification of Zeami's own Yamato style with role playing or "imitation," momomane (Rimer and Yamazaki 1984, 38). A mediation of these two concepts, under the presiding aspirational imagery of the flower, occupies much of the labor of the treatises, one that is rendered fraught by the elusiveness of taste in the dominant patrons. ${ }^{16}$

In Füshikaden, an outstanding performer is "one whose speech lacks no refinement and whose appearance creates a feeling of grace." In Kakyo (1424), "grace is best represented in the character of the nobility," their appearance, and their way of speaking (pp. 3 and 93 respectively). Those from the lower orders who are represented in $n \bar{o}$ must "exhibit the same appeal, despite whatever differences they may show in their social positions." By "living in the capital, an actor is in the proper environment." And "if the praise he earns is not from those who live in the capital, it can have little significance for him" (pp. 94, 96 , and 95 respectively). Yugen is a certain sign of acceptance and status for Zeami: it is considered "the highest ideal of perfection in many arts" and thus can be regarded as "the highest principle" of the $n \bar{o}$ (p. 92, again from $K a k y \bar{o}$ ). Creating a composed performance that accords with the taste of the nobility-and maintains it with the continuity afforded to poetry-is the intricate and paradoxical aspiration of these written treatises for an ephemeral art.

\section{The Discourse of Theory}

European poetics is significantly lacking in a myth of origin, although modernity has often made use of the Greek experience to create one. Epic poetry, of course, alluded to the muse or the Muses, though the Homeric poems are modest on the subject. (The muse is no more than thea, "goddess," in the first line of Homer's Iliad.) Only Hesiod is expansive in his Theogony. In the opening of that poem, Hesiod is approached by these daughters of Zeus on Mount Helicon and more or less compelled to sing of the gods and the Muses. But this 
seems little more than an elaborate conceit founded on the formulaic, invocatory appeal to a muse found in the opening lines of the Homeric epics. Their specializations were established far later, and for Aristotle they are of no importance whatsoever. Nor, indeed, is the imposing figure of Dionysos, whose ecstatic divinity presided over the theatrical festivals of Athens. The historical or social beginnings of tragedy and comedy do find a place in his introductory discussions in the Poetics, but they enter (in chapter 3) as rival claims based on etymology and dialect, or as the barest of developmental schemes, which takes two existing forms of celebration (dithyramb and phallic songs) and posits them cursorily as antecedents.

The lack of a divine charter for both epic and tragedy-or even for comedy and satyric drama, which were nothing if not explicitly Dionysiac-is striking, and its absence must direct us to a substitute. There is, certainly, some possibility of finding one in the briefly stated theory of katharsis, which is perhaps the most fascinating and enigmatic of all the theoretical topics in the Poetics. ${ }^{17}$ Katharsis has a remarkable resonance in Greek culture, because it combines connotations of medical purging with those of religious purification, allowing Aristotle to claim for tragedy a function that had the widest possible implications for personal and public good. ${ }^{18}$ The ceremonies introducing the dramatic festivals included a purification of the theatre, and much of modern criticism and theory has inclined to understand tragedy and comedy as religious drama, often with an emphasis on the ritual scapegoat and the sacrifice. ${ }^{19}$ It would not be an exaggeration to state that the lack of a divine charter in the leading theoretical source of antiquity has prompted modern criticism to concentrate at least some of its energies on supplying one-whether in Nietzsche's heady combination of Apollo and Dionysos (Nietzsche 1967) or in Girard's immensely influential sacrificial theory, an anthropological substitute for ancient religious belief (Girard 1977).

Aristotle first defines tragedy at the opening of chapter 6 of the Poetics in the famous formulation beginning: "Tragedy, then, is a representation of an action that is worth serious attention, complete in itself, and of some amplitude" (Aristotle 1965, 38-39). The representation is of human beings performing actions, and the definition, like the central concerns of the analysis that follows it, is quite plainly indebted to Plato, who provided his own working definition in his ruthless critique of tragedy in book 10 of the Republic: "Drama represents human beings in action, either voluntarily or under compulsion; in that action they fare, as they think, well or ill, and experience joy or sorrow" (Plato 1974, 371). It is interesting that in these typical modern translations the general term "representation" is projected onto antiq- 
uity. "Mimesis" and its cognates are used by both Plato and Aristotle. Here Plato actually proposes that "the mimetic [art or skill, techne] imitates" (for "drama represents" in the preceding translation). For Plato, the implied reference to a techne recalls its fixed place in a descending valuation of "skills": from the user who alone really understands use, to the maker who attempts to provide it, to the artistic imitator. This order parallels an order of truth: from the ideal but intangible "forms" of things, to the skillful manifestation of them in creation, and, at the lowest level, to the realm of their imitation in art. ${ }^{20}$ For Plato, the skills of the user and those of the maker (or artisan) are superior to those of the mimic artist.

In stating that Aristotle's definition of tragedy is delayed until chapter 6 of the Poetics I am drawing attention to the fact that the presiding definition is present from the beginning and is inherited from Plato. The Poetics assumes the challenge posed by Plato in book 10 for "men who are not poets themselves but who love poetry" to mount a defense of poetry in prose, "proving that she doesn't only give pleasure but brings lasting benefit to human life and human society" (Plato 1974, 376). Aristotle's approach to this task is to leave the descriptive definition of mimesis firmly in place for poetry but to alter it significantly-which he does most effectively by identifying it with "nature," or phusis, in chapter 4 of the Poetics. Mimesis is a natural activity and fundamental to learning. This is a complete contradiction of Plato's censure, which had lack of truth or an extremely remote access to the truth as its negative criterion for poetry and art. Aristotle also deftly plays with one of those Platonic triads mentioned earlier by emphasizing the terms "poiesis" and "poietike" in relation to the art (techne) of poetry. This picks up the second of Plato's levels in skills, that of the maker or artisan (the techne of poiesis) - and identifies it with the third or lower level of mimetike. By implication, both making and imitating are natural, and Plato's presiding skill of the user or consumer is picked up in the second "natural" aspect of mimesis for Aristotle, which is the pleasure derived from looking at or listening to imitations (again in chapter 4 of the Poetics). Thus all three Platonic skills are, in this synthesis, rendered natural and functional in learning by Aristotle. It is an immensely subtle resolution of apparent distinctions and difficulties, achieved without rejecting the primary definition established by the master.

Both mimesis and the concept of action entailed by it result in the domination of plot (muthos), action, and incident in the theoretical analysis of tragedy as a poiesis, and these matters are in the control of the poietes, the playwright, who directs his own composition. The beneficial effects to be felt by the community from the proper creation 
and execution of tragedy depend on the understanding of the playwright, and Aristotle's Poetics is almost exclusively a dramaturgical theory. It is conceived from first principles as a contribution to the discourse of philosophy and is addressed-as an esoteric discourse-to that elite which might attend to discussions in the Lykaion. But it is the philosophical discourse and the philosophical logos that preside over the foundation of European poetics, and this has had a slightly bizarre result: namely, the ultimate subordination of almost all attempted theories or disciplines of the art to concepts of nature and truth. In this respect, it is interesting to note that there is no evidence whatsoever to suggest that tragedy ever regarded itself as a mimesis or that the concept had any serious artistic viability before its dubious place in the Platonic order of illusion. ${ }^{21}$

The question of authorship in the Natyasastra is bound up with the narrative strategies of the compendium. Explicitly there are three gods who provide an impetus: Brahma, who responds to a request from the gods to create a fifth Veda for all the castes; Siva, who responds to an early performance with the categorization of dance (chapter 4); and Visnu, who provides the inspiration for the vrtti (styles or modes) of performance by his struggle with the two demons Madhu and Kaitabha (chapter 22). In fact, struggle lies at the heart of the creation of drama, since the demons are insulted by the first play, which takes the form of a fight between the gods and demons, who are defeated. Their anger leads them to paralyze the performers and prompts Indra to thrash the demons with his flagpole, which becomes a symbol of the gods' protection for the stage. Brahma's resolution of the conflict is to reassure the demons that they are included in a total representation of existence, which pays close attention to dharma, artha, and kama (chapter 1). In this respect the Natyasastra in itself lays claim to the status of itihasa, as an instructive account of the affairs of gods, demons, and human beings, at the same time as it claims a comparable status for the products of its guidance as a sastra-namely, theatrical plays. This comprehensive scope entails an ambitious concept of anukarana, or mimicry, which must include the actions of all creation and by so doing can include the competence of the other sastras, as Brahma is made to claim in chapter 1 .

The narrative frame of the Natyasastra is apparent in the opening and closing chapters, and the form it takes is a result of the foundation myth's emphasis on a divine origin. Drama is conceived as a performance for the gods, with the demons initially a disruptive component of the audience, and the subsequent involvement of Siva as lord of the dance leaves the foundation of a theatre and the establishment of the preliminary rites of performance firmly in that context. 
The priestly role assigned to the natyacarya and the sutradhara, and even the sidhaka, conforms to this vital charter for the fifth Veda. This divine context is ideal for the presentation of the ordering of an art which is the sastra, but it leaves unanswered the inevitable translation of a divinely conceived art to a human level. In chapter 36 , the myth of Urvasi, one of the apsaras or heavenly dancers created by Brahma to dance gracefully in the original performance, offers a traditional vehicle for a descent from heaven to earth, since she is drawn to the king Pururavas. ${ }^{22}$ But since Urvasi herself is withdrawn again to heaven, this myth is itself framed in chapter 36 by a further account, which has the king's grandson, Nahusa, requesting substitutes for Urvasi, who are provided by the sons of Bharata. They are then able to unite with the women of the harem of the king, who had been taught by Urvasi, and provide a lineage of performers. On the condition of their fulfillment of the prescriptions of the sastra, the sons of Bharata are permitted to return to heaven.

The complexity of this translation from heaven to earth, and its narrative postponement in the sastra, are the result of the conflict between the aspirational claims of the "art" in its treatise and the low status accorded to performers. In chapter 36 the sons of Bharata became drunk with knowledge of the Natyaveda and produced a lampoon of the sages-who cursed them by expelling them from the caste of Brahmins and placing them among the Sudras, the lowest caste. It is Bharata who acts as a mediator and directs them to accept the opportunity presented by the request of the king Nahusa. The effect of this narrative subtlety is to reconcile the existence of a sastra and a fifth Veda with the performance of drama for all the classes, including the Sudras, prescribed in the opening chapter of the compendium. ${ }^{23}$ But the sastra itself must not be compromised, and the concluding sections of chapter 36 reiterate its divine origins as a discourse, promising those who follow it comprehension of all the other sastras and the achievement of a merit that accords with those who practice sacrifice and study the Vedas with divine approval.

The complex charter and justification of the concluding chapter of the Natyasastra is, like the treatise as a whole, a narrative recounted to the sages who question Bharata himself. The framework of question and extended answer is made explicit repeatedly in the opening of the treatise (chapters 1, 2, 5, and 6), prompting responses on the origins, on the playhouse, on the preliminaries, and on the rasas, and is understood to cover the categorizing narrative until its renewal at the opening of the final chapter. But this concluding chapter, with its reference to the amplifications made to the sastra by Kohala and the sons of Bharata, returns to the subject of the composition of 
the treatise, which extends beyond the personage of Bharata. In this respect, it exhibits the same embracing knowledge of itself that we find in the very first chapter, where Bharata is initially introduced in the third person in his dialogue with the sages. The narrative and authoritative persona of Bharata is distanced in the frame from absolute ownership of the text as a document.

The text itself contains one further aspect that complicates our understanding of it as a discourse. In the opening to chapter six the sages request of Bharata an explanation of the "digest" or "thesis" (samgraha) alongside those of the "memorial verses" (karika) and "etymology" (nirukta). It is clear from Bharata's response (6.8-11) that the core element of these three terms is the aphoristic sutra, typically expressed in the (memorial) verse or verses that offer a rule or meaning, possibly reliant on etymology; when accompanied by a commentary, these form the digest, or samgraha. Chapters 6 and 7, which contain the discussion of the emotional theory of bhavas and rasas, with the audience prominent in consideration, are indeed composed as a commentary surrounding and amplifying a set of these memorial verses, which are quoted directly. This format is particularly prominent in chapter 7, where the first memorial verses announce a relatively plain aesthetic order dependent on etymology: a bhava is an instrument of causation, which makes something "pervade," and so words and gestures illustrating the bhavas permit the meaning of the playwright to "pervade" the audience. In the traditional verse of 7.6, the determinants and consequents that control the bhavas are themselves "things which are created by human nature and are in accordance with the ways of human nature and with the ways of the world" (Ghosh 1967, 120). Most noticeably, the traditional verse of 7.7 in referring to rasa uses the metaphor of fire, the rasa spreading over the body as fire consumes a dry stick. This image seems to be completely detached from the more familiar metaphor of "taste" (itself expressed in other verses in 6.31-33), and apparently is designed to describe an effect rather than analyze a process.

The subsequent account of the bhavas, which forms the substance of chapter 7, is heavily based on memorial verses related to each state, with the treatise adding a commentary that is in many respects no more than a recapitulation of what is contained in the verses. Thus love, laughter, sorrow, and so forth are to be shown by an engagingly simple form of physical mimicry, or anukarana, appropriate to each state. In its most appealing form, this kind of precept offers observations such as "death . . . should be represented by the absence of any further movement of the body" (7.89; Ghosh 1967, 144). It is noticeable that the concluding sattvika states of the chapter, which are them- 
selves perhaps the extreme of physical representation by the actor (sweating and goose pimples are two of them), are accompanied by no memorial verses (7.93-106). Since physicality is the express concern of the imitation already prescribed in the verses for the preceding bhavas, this is perhaps not surprising. There is only one reference in the memorial verses quoted in the chapter to the other sastras, and that is descriptive, when the state of "assurance" is to be portrayed in the theatre by an actor instructing pupils and explaining the sastras (7.82). The aesthetics of these verses of chapter 7, as observations on the art of performance, encode a relatively simple if detailed form of imitation, mimicry, or anukarana, which is far from carrying the conceptual connotations of the cosmic and universal "representation" determined by Brahma. But that is because the Natyasastra is very far from being just a handbook for performance, even for the playwright or the natyacarya or sutradhara to whom it is often implicitly addressed.

Both etymology and memorial verses play their part in Zeami's discourse, who has one complete treatise (Kȳui) composed as a commentary upon mystical aphorisms. But the intertextuality of the treatises is by no means confined to the influence of Zen Buddhism, as might be concluded from Zeami's later life and the tenor of $K y \bar{u} i$, including as it does quotations from Mencius, Confucius' Analects, and waka poetry. Also important in Zeami is a principle of monomane, or imitation, a term that modulates in the treatises from the relative simplicity of mimicry-such as that found in chapter 7 of the Natyasastra - to an imposing problematic of an art. As role playing is seen to be essential to the characteristics of Zeami's inheritance of Yamato sarugaku, so mimicry is essential to role playing, and it features early in Füshikaden. Movement, gesture, and manner of speaking are clearly components of monomane, but costume may carry a great deal (emphasized in relation to women, mad persons, and warriors), as may the handling of defining properties (a fan, a sword); facial expression must not be an object of monomane. But the presiding prescription is emphatic: "Role playing involves an imitation, in every particular, with nothing left out" (Rimer and Yamazaki 1984, 10).

The governing principle seems simple enough, and in its ideal form would be dependent on observation, but the simplicity is from the beginning subject to qualifications. So "playing the part of a ruler or a high official" will confront the actor with his inevitable ignorance of the manners of the court nobility (ibid.). Similar problems affect the portrayal of women of high rank, but the deficiencies may be made up by feedback from appropriate members of the audience (noble males) and tactful inquiry and investigation (noble women). These comments apply explicitly to compensation for the difficulties 
of direct observation in given cases, and with regard to "an ordinary woman" or to "persons of high profession" monomane can apparently operate directly (pp. 11 and 10 respectively). Yet this apparent simplicity of mimicry may be misleading. The commonplace actions of laborers and rustics must not be "copied too realistically," and a general principle is asserted that "men of lowly occupation should not be imitated in any meticulous fashion, nor shown to men of refined taste." Yet those who "have traditionally been found congenial as poetic subjects" (woodcutters, grass cutters, charcoal burners, salt workers) may be imitated in detail. This leads to the formulation of a second general principle: "The degree of imitation must vary, depending on the kind of role being performed" (p. 10). It is a principle that appears later in $K a k y \bar{o}$ in close association with yugen and the governing metaphor of the flower, which is introduced to provide a resolution of the inherent problem:

No matter what the role-whether the character be of high or low rank, a man, a woman, a priest or lay person, a farmer or country person, even a beggar or an outcast-it should seem as though each were holding a branch of flowers in his hand. In this one respect they exhibit the same appeal, despite whatever differences they may show in their social positions. [p. 94]

As a discursive term of the treatises, monomane charts the intense and subtle transition from the overt, satirical mimicry of early sangaku to the delicate compromises that reflect the presiding taste of the nobility. But monomane also has different operations to perform within the texts. It may, for example, express the relationship between teacher and pupil. Here again the apparent simplicity of monomane (representing a sound tradition of in-body learning) contains the problematic of the relationship. A pupil must imitate, but superficial imitation is not the art (Shikadō); and the teacher must not expose his highest levels of attainment to imitation by the pupil but should offer only what the pupil can follow (Kakyō, pp. 66 and 87 respectively). In this respect, monomane in the treatises operates as a control on the effectiveness and possible errors of monomane in the tradition of oral teaching: as Shikadō states plainly at its conclusion, the treatises are written because not just any training will do (pp. 72-73). ${ }^{24} \mathrm{~A}$ similar operation for the term is found in discussions of the relationships between actors, where monomane must not be restricted to the exclusive imitation of what is superior, as might be assumed (Füshikaden, pp. 24-25). It may also introduce the distinction between "function" and "substance," or "externalization" and "internalization," in the imitation of acting, which may follow the surface of excellence rather than the spirit 
(Shikado, pp. 71 and 66 respectively). In this respect, monomane introduces the hidden-much as it does in the discussion of the portrayal of the mad or possessed, where the mimicry of their external state is nothing without the imitation of the dominant feeling or the possessing spirit (Füshikaden, pp. 13-14).

In its ultimate expression, monomane will cancel itself completely-as it does in the portrayal of the old man by the "truly gifted player" who becomes the role and has "assumed the personality of an old man." Although the illusion persists for the audience, the actor will actually play the part like the youth the old man would like to be. This inversion is a paradox of imitation, and once again the problematics of monomane resolve themselves in the metaphor of the flower: such an outstanding portrayal is like "a flower blooming on an ancient tree" (Füshikaden, pp. 55-56). The instability ascribed to monomane by Zeami leads inevitably to the flower as the governing metaphor of aspiration in the treatises-much as the mastery of the problems of role playing is the absolute preliminary to an understanding of "the flower that does not fade" in Füshikaden (p. 30). The goal of success lies in the image of the flower, but success itself may be illusory if it is only temporary (pp. 37 and 39). While monomane may be adjusted to the demands of yugen, in the compromise between the Yamato and Omi styles of performance that inspires the composition of the treatises, the metaphorical range of the flower offers a far more impressive set of resolutions. Thus the flower is a mediating principle between styles, even including dengaku, which "represents quite a different form of art from our own." Füshikaden contends: "Styles of acting and the basic forms of art may differ variously, but what is effective about each is common to all. This moving quality is the Flower. It is recognised as crucial to Yamato and Omi sarugaku and to dengaku as well" (p. 39).

"This moving quality" readily expresses the range and capability of metaphor, which may conjoin what is apparently different in the conviction of a resolution. As a consequence, it can mediate between a country audience and the nobility, in the person of the player who possesses it (p. 50), and can cover the appeal of different levels of attainment to such audiences: "Now, as concerns the Nine Levels, it goes without saying that the flower is manifested in the upper three levels, yet in the middle three and lower three levels of our art as well, insofar as they possess elements of interest, there are appropriate flowers for them as well" (Shügyoku tokka, p. 130). The upper three are for the "highly cultivated"; the middle and lower, it seems, are for "farmers and rural people."

The ambition represented by the image of the flower summarizes Zeami's aspirations for the transcendence of cultural obstacles facing the ideal $n \bar{o}$ performer. The ambition is present in the image, 
which is one of attainment and manifestation (and so of consummate approval from an audience) whenever it is applied. But the aspirations apply to what may appear to be irreconcilable. Thus in chapter 5 of Füshikaden, the actor who has mastered "the real secrets of his art" and has "achieved his Flower" will be respected everywhere and will "perform ably in the style of Yamato and Omi sarugaku, and even in the style of dengaku, depending on the wishes of his audience" (p. 40). The image contains and transcends a serious paradox, since the claim to universal respect is deeply problematic if an audience without discrimination cannot appreciate a good player. But the flower does not wither in such circumstances: "Thus, while it is true that an untutored audience may not be able to grasp the elements that make a performer good, and thereby appreciate him, nevertheless a truly gifted player, if he really makes use of all his artistic skill, should be able to move even an undiscriminating audience" (pp. 39-40).

The tasks set for the image by aspiration are daunting. Not only must the actor know all the styles, but he must also master his own. And unless he does so he will "not only fail to grasp the fundamentals of his own proper art but will certainly fail to understand any of the others," or the flower will elude him (ibid.). The problem of different flowers and different audiences and their levels of appreciation leads to a variety of evasions. Hence Zeami suggests that in order to please a provincial audience the actor may need to draw on "the easy style of performance he used when a beginner"; yet when a good actor faces a withdrawal of favor "because of some situation over which he has no control," he may retain his flower by performing in the provinces (pp. 41 and 42 respectively).

It is, of course, the image that must be retained by theoretical aspiration, even at the cost of a temporary loss of conviction. And if metaphor is to be retained, it must be allowed to collapse under the strain into something more potent. It cannot hold in all circumstances. A good play may be performed in front of a discerning audience by a good player, but it still may not succeed: although the balance of yin and yang may be to blame, Zeami is obliged to admit that, contradictory as it may seem to the terms in which he has framed the example, one of the only answers is to assume that the actor has actually failed to "achieve the proper flower" (p. 45). It is in the secret teaching of chapter 7 of Füshikaden that Zeami finally acknowledges that the range of metaphor is in fact banal and something further is required for the image. If "the flower can be used . . . as a metaphor for all things in the $n \bar{o}$," and mostly describes what "seems novel to the imagination of the spectator," then its attempted application to all discursive circumstances will result in its degradation, prompted by an eventual failure to resolve or to reconcile successfully (pp. 52-53). The 
antidote to this debasement of a vital currency is the discovery, or the invention, of the gold standard-namely, the meta-metaphor, the collapse of the metaphor into itself to emerge as a symbol: "The player who has studied his art to its furthest reaches will come to know the Flower that lies within the Flower" (p. 55).

This extremity of remote aspiration can be located in the "Flower drawn from past and future," a symbol that is introduced toward the close of Füshikaden only to be apparently withdrawn, since "no one has ever heard of such a supremely gifted artist from the beginnings of our art down to the present day" (p. 57). But the composition of the treatises as a compelling charter for the Kanze house ensures that there must be one exemplar, as writing enshrines the founding father of achievement, Kan'ami. Ultimately the treatises are the secret, and the secret lies in the treatises, from which it can never be fully extracted, because once recognized actual achievement vanishes: "Where there are secrets, the Flower exists; without secrets, the Flower does not exist" (p. 60).

\section{Concluding Comments}

After opening out a discussion of all three bodies of writing, I do not wish to offer a misrepresentative closure in the form of summarizing conclusions. I have considered related questions of status and discourse, but there are many other issues of equal importance that one might add to a discussion of this kind. Plainly a consideration of the theoretical discourses from the point of the addressees is bound to be intriguing - to different degrees in relation to each-but we should probably resist the temptation to ascribe the composition of theory to a kind of humanist pragmatism. So, with Aristotle, we can assume a manifest address in the Poetics to the potential playwright (in contrast to the actor) or poet, but the address to Plato and the continuing discourse of philosophy in the Greek schools is even more pronounced. The Natyasastra codifies procedure and possibility most explicitly for the director or supervisor of a company, at times shifting its address to the playwright, but its immediate addressees, the sages who question Bharata, are part of a far more imposing fiction that is essential to the work. With Zeami, the picture is complex in a different way. The head of the school, and the succession, are an overt concern, and the accent lies heavily on excellence by the actor in performance. But there is an accompanying expectation in the dialogic portion of Fushikaden (chapter 3) that figures of this sort should expect to compose their own scripts (pp. 21-22) in a more satisfactory alternative to the task of selection and interpretation; and instruction and ultimately models are given in the later Sando (pp. 148-162). The 
composition of scripts, as in Aristotle and the Natyasastra, is brought firmly under theoretical control and, like performance, is subject to the potentially transcendent model established by the theorist Zeami. ${ }^{25}$ If there is an invitation to apparent addressees in all three bodies of material, it is by no means an invitation to the kinds of artistic initiative that created the form.

That theory has its own dynamic of continuity is quite clear, not just from the example of the Poetics in Western thought, but from works in the Sanskrit and Japanese traditions that have not entered into this discussion. The Natyasastra inspired both commentary and digest, and its modern interpretation would not take the form it has without the vision of Abhinavagupta and his reading in the Abhinavabharati. ${ }^{26}$ The composition and compilation of Sarugaku Dangi by his son Motoyoshi redefined Zeami in the role he had assigned to his own father, and recent publication has explored the quality and significance of Zeami's immediate theoretical successor, Komparu Zenchiku. ${ }^{27}$ In Zenchiku's vision of Six Circles and One Dewdrop, the sense of attainment he received from his teacher Zeami is rendered into a symbolism relatively devoid of pragmatic instruction or reference to dramaturgy. In its turn, it is itself then susceptible to commentary from Buddhist and Confucian sources, as Thornhill has closely examined; in fact, the text contains these commentaries and renders them into a further synthesis (Thornhill 1993; Nearman 1995). For Zenchiku, therefore, the first sphere of his symbolic order represents "the spirit that circulates, flowing without ceasing even for a moment," to which Nearman adds the following commentary:

That is, even though the first sphere is presented by a static, twodimensional circle, this diagram is intended to convey the idea of ceaseless movement, a circulation of undifferentiated energy that is omnidirectional, and like a bird's egg, it contains all that is necessary for the ultimate production of a vital phenomenal manifestation. [Nearman 1995, 249]

This is theory in its most transcendent mode-and as striking a confirmation of its existence as discourse as one might expect to find.

\section{NOTES}

I am grateful to the University of Exeter for a research grant in support of this study and, as well, to the staffs of the Library of the Indian Institute and the Japanese Library in the Nissan Institute in Oxford for their help. My thanks are also due to Samuel L. Leiter and Marvin Carlson. 
1. For examples see Megumi (1989), Sukla (1977), Gupt (1994), and Smethurst (1989), who cites Japanese comparative scholarship. Gopalakrishnan (1991) and Rajakaruna (1993) offer short, comparative studies of Indian and $n \bar{o}$ theatre. The reader should note that my bibliography, for reasons of space and proportion, is indicative only.

2. Janko (1984) discusses the evidence for the contents of a second book of the Poetics and presents a tentative reconstruction.

3. The ancient Greek tradition holds that Aristotle's esoteric works were transmitted by successive heads of the Peripatetic school of philosophy; see the introduction to Lucas $(1968, \mathrm{x})$.

4. These early chapters of book 3 also refer to the existence of a techne literature on the "art" of style and delivery (performative speaking) in rhetoric.

5. Translations and studies of Aristotle's Poetics abound. Here I mention one commentary (Halliwell 1986), one collection of essays (Rorty 1992), and one monograph (Belfiore 1992).

6. The debate goes back as far as the earliest major commentator, Abhinavagupta. For discussions see, among others, Gupt $(1994,29 \mathrm{ff}$.) and Dasgupta and De (1962).

7. See the essay by Gerow, "Sanskrit Dramatic Theory and Kalidasa's Plays," in Miller (1984, 42-64). This volume includes a translation of Kalidasa's Vikramorvasiya (Urvasi Won by Valor) by D. Gitomer.

8. See Keith (1924, 12-13) and MacDonell (1900, 284, 288-289, and 294) on Vyasa, the mythical compiler of the epic, who had supposedly arranged the four Vedas.

9. On the sutras see MacDonell (1900, chaps. 2 and 9); part 3 of Keith (1920) is devoted to what he terms the "Scientific Literature," namely the sastra writings. The reader should note that the date of Keith's edition is as given on the title page; but his preface indicates (pp. viii and xxviii) that the book was actually published in 1928 and certainly after the publication of Keith (1924).

10. One division of the sutra literature had dealt with the rites that might be performed by the householder and his wife in accordance with the Vedas; see MacDonell (1900, 37). But this should not, in principle, affect our understanding of the status afforded to the natyacarya and sutradhara by the Natyasastra in the context of the ritual dedication of the theatre.

11. All quotations from the treatises of Zeami are taken from this volume of translations, which has become a standard textbook. For comparison, Nearman (1984) gives details in his bibliography of his annotated translations of selected treatises (including Kakyō) for Monumenta Nipponica, while de Poorter (1986) provides an annotated translation of the Sarugaku Dangi, a compilation to which I do not refer in this discussion. De Poorter's "Appendix 1" (1986, 242-249) usefully lists all the writings of Zeami with indications of date and subject, and cites translations in English, French, and German.

12. For the biography of Zeami see Hare (1986, chap. 1).

13. For the myth of Amaterasu in the Nihongi see Aston (1896, 41-45). 
14. On yugen as a criterion in poetic theory see Putzar (1973, 63-64) and de Poorter: "From the twelfth century this word was used in Japan for the judgement of poems" $(1986,55)$. Compare Ueda Makoto (1991, 40), who declares of the fourteenth-century usage by the poet Yoshimoto that "the term seems to designate a certain idea roughly equivalent to elegance, gracefulness, or polished beauty." On the problems of translation for the term in Zeami see Hare (1986, 300), who seems to prefer "elegance"; compare Rimer and Yamazaki $(1984,260)$, who opt for the use of "grace" throughout.

15. On the imagery of blossoms and flower in Tsurayuki and Yoshimoto see the examples given by Ueda (1991, 8 and 41).

16. Most biographical and critical accounts attach great importance to the issue of taste in the successive shoguns and the audience. See, for example, Raz (1983, 70-122), Hare (1986, 11-38), and Konishi (1991, 520-560).

17. The famous formulation of katharsis occurs at the beginning of chapter 6 of the Poetics.

18. For a wide variety of interpretations of katharsis in the Poetics see the essays collected by Rorty (1992).

19. On the celebration of the dramatic festivals see the essay by Goldhill, "The City Dionysia and Civic Ideology," in Winkler and Zeitlin (1990); see also the essay by Cole, "Procession and Celebration at the Dionysia," in Scodel (1993).

20. See Plato (1974) on the three skills (pp. 367-369) and on the descending order of knowledge (pp. 359-364).

21. On mimesis and related terms before Plato see Else (1958).

22. The myth of Urvasi is found in the most ancient of the four Vedas, the Rig-Veda, book 10, number 95; for a translation with notes and a short commentary see O'Flaherty $(1981,252-256)$.

23. The claim that drama allows for the instruction of all castes, including the Sudras who were excluded from listening to the Vedas, was also made on behalf of the Mahabharata; see MacDonell (1900, 289).

24 . The control exercised by the treatises on the oral or in-body teaching is also made apparent in the Kakyo's concern that proper principles should be followed in the certification of pupils (p. 88).

25. Quinn (1993) observes that Zeami's assumption in Sandō that performers were "capable of composing both the lines and the music of their own plays" was "unprecedented" but came to be the norm: "Collaboration was the more common practice, sarugaku professionals composing the music and poets composing the lines" (p. 55). It is interesting, here, to compare the situation in relation to the substantially untheorized (and later) kabuki; see Dunn and Torigoe (1969, 20-21 and 118).

26. On the value of Abhinavagupta see the short summary by Ghosh (1961, xlvii-xlix). Gupt (1994) makes extensive use of the commentary and provides a summary of rasa criticism up to and including the Abhinavabharati in the eleventh century (pp. 260-271); the analysis on pp. 236-247, which reproduces his own argument in Gupt (1990), is a good example of its weight in the interpretation of significant concepts. There is a translation of the 
immensely influential part of the Abhinavabharati that refers to chapter 6 of the Natyasastra in Gnoli (1956); see also Chari (1990).

27. For the Sarugaku Dangi, in addition to the translation in Rimer and Yamazaki (1984, 172-256), see de Poorter (1986). On the transmission from Zeami to Komparu Zenchiku see Pinnington (1997). Zenchiku's treatises, and the commentaries upon them from Buddhist and Confucian sources, are the subject of Thornhill (1993); Nearman has provided a series of annotated translations, comparable to those he executed for Zeami, of the Rokurin Ichiro treatises of Zenchiku in four successive issues of Monumenta Nipponica (beginning with Nearman 1995).

\section{REFERENCES}

Aristotle. 1965.

On the Art of Poetry. Translated by T. S. Dorsch. In Aristotle, Horace, Longinus: Classical Literary Criticism. Harmondsworth: Penguin. 1991.

The Art of Rhetoric. Translated by H. C. Lawson-Tancred. Harmondsworth: Penguin.

Aston, William G., trans. 1896.

Nihongi: Chronicles of Japan from the Earliest Times to A.D. 697. London: Kegan Paul.

Belfiore, Elizabeth. 1992.

Tragic Pleasures: Aristotle on Plot and Emotion. Princeton: Princeton University Press.

Chari, V. K. 1990.

Sanskrit Criticism. Honolulu: University of Hawai'i Press.

Dasgupta, S. N., and S. K. De. 1962.

A History of Sanskrit Literature, Classical Period. 2nd ed. Calcutta: University of Calcutta Press.

de Poorter, E. 1986.

Zeami's Talks on Sarugaku: An Annotated Translation of the Sarugaku Dangi. Amsterdam: Gieben.

Dunn, Charles J., and Torigoe Bunzo, eds. and trans. 1969.

The Actors' Analects. New York: Columbia University Press.

Else, Gerald F. 1958.

"Imitation in the Fifth Century." Classical Philology 53: 73-90.

Ghosh, Manomohan, trans. 1961.

Natyasastra. Vol. 2. Calcutta: Asiatic Society.

- 1967.

Natyasastra. Vol. 1. 2nd ed. Calcutta: Manisha Granthalaya.

Girard, René. 1977.

Violence and the Sacred. Translated by P. Gregory. Baltimore:Johns Hopkins University Press.

Gnoli, R. 1956.

The Aesthetic Experience According to Abhinavagupta. Rome: Istituto Italiano per il Medio e Estremo Oriente. 
Gopalakrishnan, S. 1991.

"Kutiyattam and Noh: Commonalities and Divergences." Sangeet Natak 99:35-42.

Gupt, Bharat. 1990.

"Clarification on Lokodharmi and Natyadharmi." Sangeet Natak 95:35-44. 1994.

Dramatic Concepts, Greek and Indian: A Study of the Poetics and the Natyasastra. New Delhi: D. K. Printworld.

Halliwell, Stephen. 1986.

Aristotle's Poetics. Chapel Hill: University of North Carolina Press.

Hare, Thomas B. 1986.

Zeami's Style: The Noh Plays of Zeami Motokiyo. Stanford: Stanford University Press.

Inoura Yoshinobo. 1971.

A History of Japanese Theatre. Vol. 1: Noh and Kyogen. Tokyo: Kokusai Bunka Shinkokai.

Janko, Richard. 1984.

Aristotle on Comedy: Towards a Reconstruction of Poetics II. Berkeley: University of California Press.

Keith, Arthur B. 1920.

A History of Sanskrit Literature. London: Oxford University Press. 1924.

The Sanskrit Drama. London: Oxford University Press.

Konishi Jin'ichi. 1991.

A History of Japanese Literature. Vol. 3: The High Middle Ages. Translated by A. Gatten and M. Harrison. Edited by E. Miner. Princeton: Princeton University Press.

Lucas, Donald W., ed. 1968.

Aristotle Poetics. Oxford: Clarendon Press.

MacDonell, Arthur A. 1900.

A History of Sanskrit Literature. London: Heinemann.

Megumi Sata. 1989.

"Aristotle's Poetics and Zeami's Teachings on Style and the Flower." Asian Theatre Journal 6(1):47-56.

Miller, Barbara S., ed. 1984.

Theater of Memory: The Plays of Kalidasa. New York: Columbia University Press.

Nearman, Mark J. 1984.

"Feeling in Relation to Acting: An Outline of Zeami's Views." Asian Theatre Journal 1(1):40-51.

1995.

"The Visions of a Creative Artist: Zenchiku's Rokurin Ichiro Treatises." Monumenta Nipponica 50(2):235-261.

Nietzsche, Friedrich. 1967.

The Birth of Tragedy and The Case of Wagner. Translated by W. Kaufmann.

New York: Vintage.

O'Flaherty, Wendy D. 1981.

The Rig Veda: An Anthology. Harmondsworth: Penguin. 
Pinnington, N. J. 1997.

"Crossed Paths: Zeami's Transmission to Zenchiku." Monumenta NipPlato. 1974. ponica 52(2):201-234.

The Republic. Translated by D. Lee. Harmondsworth: Penguin.

Putzar, E. 1973.

Japanese Literature: A Historical Outline. Tucson: University of Arizona Press.

Quinn, S. F. 1993.

"How to Write a Noh Play: Zeami’s Sandō." Monumenta Nipponica 48(1): 53-88.

Rajakaruna, D. A. 1993.

"The Classical Noh Theatre of Japan: An Indian Approach." Sangeet Natak 108-109:17-22.

Raz, Jacob. 1983.

Audience and Actors: A Study of Their Interaction in the Japanese Traditional Theatre. Leiden: Brill.

Rimer, J. Thomas, and Yamazaki Masakazu. 1984.

On the Art of the Noh Drama: The Major Treatises of Zeami. Princeton:

Princeton University Press.

Rorty, Amélie O., ed. 1992.

Essays on Aristotle's Poetics. Princeton: Princeton University Press.

Scodel, Ruth, ed. 1993.

Theater and Society in the Classical World. Ann Arbor: University of Michigan Press.

Smethurst, Mae. 1989.

The Art of Aeschylus and Zeami. Princeton: Princeton University Press.

Sukla, A. C. 1977.

The Concept of Imitation in Greek and Indian Aesthetics. Calcutta: Rupa.

Thornhill, A. H. 1993.

Six Circles, One Dewdrop: The Religio-Aesthetic World of Komparu Zenchiku.

Princeton: Princeton University Press.

Ueda Makoto. 1991.

Literary and Art Theories in Japan. Ann Arbor: University of Michigan Press.

Winkler, John J., and Froma I. Zeitlin, eds. 1990.

Nothing to Do with Dionysos?: Athenian Drama in Its Social Context. Princeton: Princeton University Press. 